DOI: $10.20535 / 2411-1031.2018 .6 .1 .153125$

UDC 004[853+55]

\author{
ANATOLII HLADUN, \\ YULIIA ROHUSHYNA, \\ IHOR SUBACH
}

\title{
AN ONTOLOGY MODELLING HUMAN RESOURCES MANAGEMENT FOR INNOVATIONAL DOMAINS
}

We propose objective methods of the semantic comparison of the business task description with documents describing competencies of applicants. The advantages of qualifications describing through the triad of professional qualities - knowledge, skills and competencies - are demonstrated. Scientific novelty of this work deals with the use of atomic competencies as a main component of original ontological qualification model that becomes an instrument for solving of the complex scientific problem of qualification matching. The authors develop the original ontology that describe the high-level relations of employers and employees. This ontology can be integrated with domain and organizational ontologies that specialized these relations for some concrete task. Such approach can be useful for innovation domains (new or multidiscipline) where expert groups and formal specifications of professional skills stand on stage of formation. Information acquired from natural language documents that characterize applicants is represented by ontology-based thesauri that objectively reflect area of expertise of participants and thesaurus of project built by it's natural language descriptions. Than these thesauri are matched on semantic level to define what part of such competencies is relevant to project needs. These methods provide the detection of the most relevant specialists able to carry out specific tasks of new promising domains. The retrieval can be provided in the Web-open environment or in natural language documents proposed by applicants. The results of this research can be used for Human Resources Management in automated semantic evaluation of competencies for new and multidiscipline subject domains deal with scientific research and knowledge processing that evaluated by scientometric measures. Proposed methods uses domain knowledge and information about structure of research activities formalized by ontologies. These methods are based on semantic matching of description of the documents (diplomas, certificates, articles, monographs, conference materials, Web sites etc.), describing the competence of standard developers in chosen domain.

Keywords: competence, ontology, knowledge processing, innovation domain, human resources retrieval, human resources management, research activities, scientometric indicators.

Problem Statement. Human Resources Management (HRM or HR-management) is a complex multi-discipline problem that is based on efforts of researchers of various spheres. Now it actively use modern informational technologies that provide semantic processing of heterogeneous resources of the Web. The main challenges faced by Human Resources (HR) functions for innovation domains include those ones that deal with the rapid start-up and the requirement to provide new operations as they mature through different stages of the business life-cycle, the changing capabilities of international operations, the staffing of strategic integration teams. The effective management of human resources is a major determinant of success or failure in various spheres of business. Globalization brings the HR function closer to the strategic core of the business and also leads to considerable changes in the HRM content. There is an important amount of investment in human capital for economic development. HRM refers to the effective use of human resources for raising of the organizational performance [1].

The main functions of HRM deal with tracking of data about each employee from their personal records (data, skills, capabilities) and experiences. HRM use the Web as an effective 
communication channel to such resources as newspaper advertisements, online job exchange services, trade fairs, co-worker recommendations and human resources advisors, online personnel marketing etc. HRM choose the most suitable standards for modeling curriculum vitas (CVs) and job offers that considered the following aspects: The degree of coverage of the objects identified in the previous task, this aspect has been evaluated taking into account the scope and size of the standard.

Analysis of recent researches and publications. The idea of human resource management has become topical and controversial. The term suggests that people in any organization are an asset to be upgraded and full utilized rather than merely a variable cost to be minimized. This in turn implies that the way in which people are managed is a matter of crucial strategic concern. Currently the Human Resource Semantic Web applications are still in an experimental phase, but their potential impact over social, economical and political issues is extremely significant. In [2], [3] a scenario for supporting recruitment process with Semantic Web technologies but just within German Government.

In [4] some dependencies between Human Resources Management and Knowledge Management in a concrete scenario. Also, at work is an effort described in [4] whose mission is to promote semantic web technology into HR/e-learning standards and applications. Its current focus topics includes: semantic interoperability, semantic of HR-XML (http://www.hr-xml.org).

In [4], [5] a generic ontology-based user modeling architecture applied in the context of Knowledge Management for HRM scenario is proposed. The bottleneck of HRM applications of Semantic Web technology is the lack of industry-strength ontologies that go beyond academic prototypes. This problem causes the need in methods and tools for design of such ontologies. Competence management $(\mathrm{CM})$ is an important research object in the more general area of $\mathrm{CM}$ that provides the identification of the key knowledge about employees and organizations.

For example, a competency model and a process of the competence management for resources related to e-recruitment ( $\mathrm{CV}$ or a Job Offer) is analysed in [6]. In [7] authors outline the main areas of HRM actual practices that include models and factors that lead to successful transfer of HR practices; the nature of HR knowledge that needs to be transferred from one international HR; acquisition of knowledge deal with HRM; and how such knowledge can be facilitated.

Now the use of ontologies for modeling of human resources management is one of the most popular approaches that try to integrate the results of semantic technologies and knowledge management with the modern challenges in human resources management (HRM). Ontologies are used to model descriptions of job offers and curricula; and for facilitating the process of exchanging job offer data and CV data between Employment Services [8].

In the work [8] of the authors, the authors use a complex hierarchy of ontologies to take into account all the knowledge and standards that apply to both the employer and the job seeker. Ontologies are used to model descriptions of work offers and curricula; and for facilitating the process of exchanging job offer data and $\mathrm{CV}$ data between employment services. This is a rather narrow-minded task, which is carried out in accordance with certain standards of the European Union countries and requirements for the qualification of the work of individual companies. Our work represents a more general approach, taking into account the information contained in the Web and thereby obtaining a faster search result and overcoming a large number of potential applicants.

In Ukraine and in neighboring countries, transformation of personnel processes is of great importance, which is a key element of the digital transformation of the entire business. In order to realize the company's business strategies, to preserve and increase the competitive advantages and increase the efficiency of the company, it is necessary to use a new approach in recruiting people for the execution of important projects. The application of intellectual technologies based on the ontological approach in this area is just beginning.

The article goal and tasks. We analyze a particular case of HRM for innovational domain where by the task natural-language description we try to find the set of specialists with actual and profound knowledge and experience in this subject domain. The difficulty of this problem is usually 
caused by the absence of specialties and occupations that matched exactly with such new domain: we need in specialists that have diplomas and certificates from the nearest domains or in the intersection of some disciplines. Therefore we consider this problem as a complex information retrieval task that deals with estimation of matching of applicant qualification with the task domain by the model of competencies that are acquired from the Web resources and other available naturallanguage documents. This problem requires semantic processing of open sources - for example, the Web information resources (IRs). Such processing has to provide the scope of domain competencies of proposed task.

The main material research. An analysis of information about the project participants from the viewpoint of HRM is a complex problem that requires the use of methods and approaches from various subject domains. Some part of this information (level of education, experience in the relevant field, the presence of previously developed projects) is clearly formalized and can be evaluated without taking into account the semantics of domain and additional knowledge about the project. But often this information is not sufficient to determine the ability to work efficiently on some specific task in the new and rapidly changing domains. HRM concepts "competence" and "expertise" are different. Competence means the knowledge and experience of person that have to provide successful execution of various tasks, and expertise describes the relation between the competence and some person. Therefore an expertise can be defined by the analysis of professional activity of specialist, her/his awareness of the science and technology achievements and problem understanding.

An objective criteria of competence evaluation that can be used in HRN sphere for scientists is an analysis of their publications accessible by the Web - their scientific articles that usually are represented by natural language documents (sometimes - with structured metadata). Parameters that determine the pertinence of such documents to discovered domain are the number of references to the domain terms in the document and the number of project terms used in the document.

However, information sources of the Web differ by their consequence and importance for person qualification. Therefor we take into account the evaluation of researcher activities by the scientific community - by the presence of references by other authors in their work. Information about researchers can be imported from a knowledge bases of intelligent applications that provide personalized information services. Thus, we propose to use as a source of information about the researcher expertise presented by natural language [9]:

- individual documents that acknowledge education and experience (for example, university diploma, academic degree, certificates and awards);

- official documents that describe the semantics of these individual documents (passports of specialties and disciplines, the requirements for obtaining of scientific titles and degrees, job descriptions, taxonomy of national academic degrees, etc.);

- intelligent property documents (published articles, abstracts, monographs, textbooks, technical reports, patents and other intelligent property) that are rate by scientometric databases and accessible by the Web;

- official Web pages of organizations and institutions deal with applicants (for example, membership in the international scientific and technical societies, editorial boards of scientific journals, scientific and educational institutions).

- personal Wiki pages of individuals and organizations with structured information;

- blogs and pages from social nets of applicants.

Use of scientometric characteristics of research activities. Scientometric characteristics that evaluate the effectiveness of scientific activities of individuals, groups and organizations can be used in HRM for describing of qualification level of applicants in new domains where experts are not defined.

The "Scientometrics" concept was introduced in 1969 by V.V. Nalimov [10]: scientometrics is a science that involves statistical studies of the structure and dynamics of scientific information flows. It studies the evolution of science through a numeric measurement of scientific information, 
such as the number of scientific articles for a certain period of time, citation, etc. The increased interest in scientometric indices is caused primarily by the ability to automate the evaluation of the results of scientific activity [11]. Scientometric indicators are suitable for estimating the results of fundamental research which demand is assessed by the references of the scientific community. Now generation of the researcher rankings use various parameters such as number of publications (in total or separately for types - monographs, articles, theses, publications in journals indexed in the Web of Science, Scopus or Google Scholar, etc.) and references to them. Sometimes the volume and impact factor of publications are took into account. Integral criteria based on these ones are formed.

The effectiveness of scientific activity can be evaluated using both qualitative and quantitative indicators. The most effective characteristics used for quantitative evaluation of scientific work productivity are the Hirsch index (H-index proposed by Hirsch [12]) and impact factor [13]. Hindex is defined by the maximum integer $\mathrm{h}$ which means that the author has published $\mathrm{h}$ papers and each of them was referred in other articles at least $h$ times. Popularity of h-index is caused by it's easy calculation and insensitivity to the typical methods of factitious improvement of considered above scientometric indicators [14]. $\mathrm{H}$-index is used in either by free public scientometric database on the Web (for example, Google Scholar, Elibrary.ru, ADS NASA) or by the database with a paid subscription (for example, Scopus or ISI Web of Science). However, many paid databases give the $\mathrm{h}$-index of scientists in the public domain. It should be noted that the Hirsch index has different rating meanings of the same researcher in dependence of the indexed IR set. Results of h-index use are more objective in the case of withdrawal of the author references to their own articles.

Impact factor is a quantitative measure of the importance of a scientific journal is calculated annually by the Institute for Scientific Information (ISI) and is published in the Journal Citation Report. It indicates the average number of links on each article that was published in the journal for the next $x$ years after its release [15]. Impact factor allows to compare different journals and research groups by formal parameters. Generally, the calculation of the impact factor is based on a three-year period.

Citation Index is an accepted by the scientific world measure of the significance of scientific work of some scientist or research team which is the total number of links in the indexed articles on reviewed publication. Citation depends not only on the level of scientific results but also on other factors, for example, the publication timeliness.

Scientometrics databases (SMDB) that used to obtain these estimates are bibliographic and abstract databases with tools for citation tracking of articles published in scientific journals.

The role of ontologies for competence estimating of specialists. An important factor of HRM is the expertise of professional experience of applicants in domain of particular project. Formal models of such domain can be represented by its ontology. Ontological analysis is now the most common approach of domain knowledge representation that provides the analyses and comparison of the competencies of experts and developers in new research areas [16].

Domain-specific ontologies can be integrated with ontology of research activities and with organizational ontologies of scientific institutions, Academy of Sciences, UDC classifier and other relevant knowledge bases [17], [18]. We propose the following ontology of research activities oriented on the determining of the competencies of the applicants (see fig. 1). The main classes of this ontology are "knowledge", "skills" and "competences". This ontology helps to define their relations with such terms specific to research activities as "publication", "monograph", "research project", "diploma", "researcher", "specialty", "academic degree", "education" and expresses such relationships between classes as "to be co-author of", "to work in the organization", "to be the author of the publication", "have a degree in the specialty" and properties such instances of classes like "to be publishing", "to have the Hirsch index" [19].

Developers of research projects can use this ontology as a model for the description and classification of the submitted documents which have to certify their competence level both in scientific work in general and in some particular research domain of information technology. 


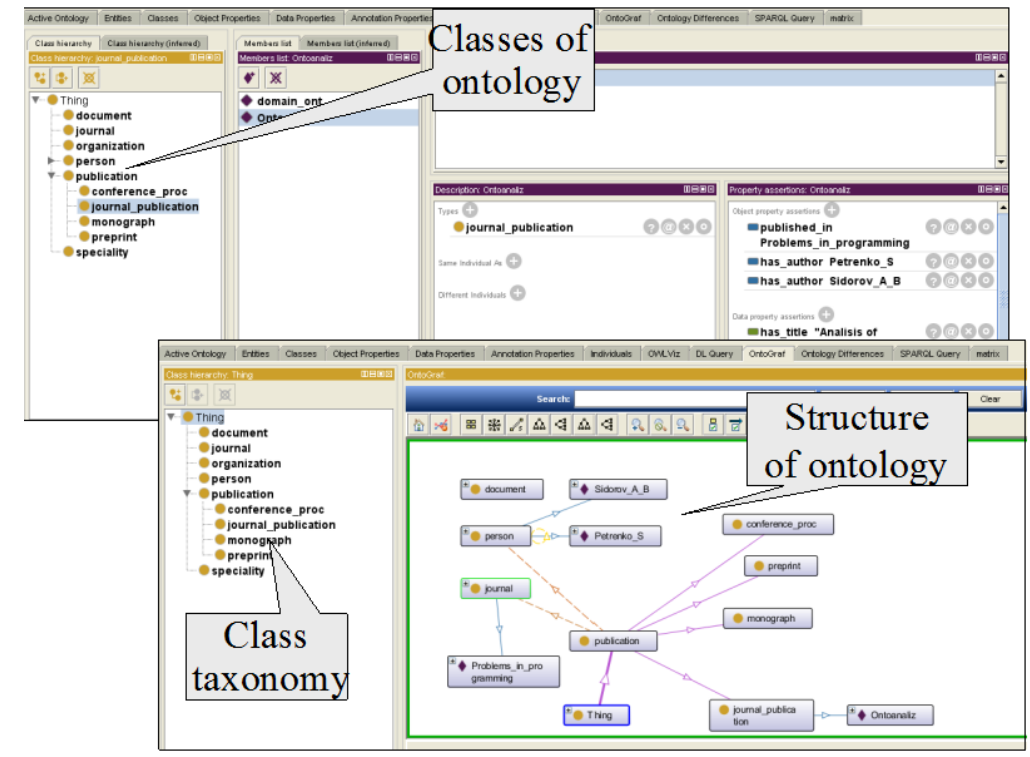

Figure 1 - Ontology of research activities

Ontology-based matching of natural language documents. Matching of natural-language (NL) documents with domain model formalized by ontology is a complex task that needs a lot of time and calculation resources. Therefor we propose to use ontology-based thesauri that simplify this task.

Thesaurus of IR can be considered as a projection of domain ontology [20]: it consists of ontology terms related with NL fragments of this IR. Thesaurus of the project participants is generated as the join of the IR thesauri with account of weight of the individual IRs which should be considered as the significance of the document to describe the competence and level of trust to this IR. For example, the weight of thesis abstract is more then the weight of diploma, and impact factor of journal can define the weight of publication.

We propose to generate the project thesaurus and thesauri of applicant IRs and then match these thesauri provides the evaluation of proximity of researchers qualification with project domain. Project thesaurus is built by NL project descriptions, and the IRs that characterize an applicant are proposed either by applicant or retrieved from the Web by HRM system. For example, if the author has $n$ scientific publications then he chooses $m$ of them that are relevant with the project. However, the author should seek to ensure that all the concepts of the domain ontology that have linguistic equivalents in the project text of these would be present in his selected works (the weight of each comparison depends on the weight of IR due to the function of the status and rating of the document). Status of document characterizes the level of documentary evidence of this type of IR and rating of document characterizes its estimation in SMDBs.

Project thesaurus $T h_{\text {proj }}$ depends on the project description and of the selected domain ontology. It is a set of pairs $\left(t_{i}, q_{i}\right)$ where $t_{i} \in T, T$ is a set of terms of domain ontology $O_{\text {domain }}=\langle T, R, A\rangle$, and $q_{i}$ is a number of matches that determines the weight of the term. NL fragments are retrieved into the IR content for each term of the domain ontology.

The overall estimation of the team competence is determined by the array $\left(t_{i}, \sum_{j=1}^{m} p_{I R_{j_{i}}} \cdot v_{I R_{j}}\right.$, where $t_{i}$ is a number of domain ontology terms from $T ; p_{I R_{j_{i}}}$ is a number of matches with this term in the $j$-th IR; $v_{I R_{j}}$ is a weight of the $j$-th IR. It is important that this array don't contain all terms of domain ontology but only those ones that have matches with project. We propose to determine the weight of every IR type according to task specifics. For example, for scientific publications these weights can take into account the impact factor of journals, number of citations, indexation of 
article by SMDBs and year of publishing. An overall estimation of the researcher is calculated as follows:

$$
C=\sum_{i=1}^{n} q_{i} \cdot\left(\sum_{j=1}^{m} p_{I R_{j_{i}}} \cdot v_{I R_{j}} \cdot \operatorname{Im} p\left(I R_{j_{i}}\right)\right),
$$

where $\operatorname{Im} p\left(I R_{j_{i}}\right)$ is an impact factor of journal that publishes this IR.

But estimation (1) doesn't use domain semantics and relations among the domain ontology terms. Therefore we proposed to use more complex estimation:

$$
C=\sum_{i=1}^{n} q_{i} \cdot\left(\sum_{j=1}^{m} p_{I R_{j_{i}}} \cdot v_{I R_{j}}\right) \cdot s_{i}
$$

where parameter $s_{i}$ determines the value of the $i$-th term of the ontology by the number of its relations with those terms of ontology that are also included to the project thesaurus and take into account the semantic distance between them [21].

General qualifications of each of the applicant can be took into account (in addition to the domain specialization) by their rating derived from SMDB. In particular, we propose to use information from Google Scholar and Scopus because this information is accessible for all the Web users.

Conclusions and prospects for further research. A new approach to solving the problem of objective competence evaluation in the context of new information and communication technologies has a lot of important features. These specifics is caused by high dynamics and heterogeneity of innovation domains that don't have acknowledged experts but are provided by the Web information resources that demand semantic processing.

The results of this research can be used for HRM in automated semantic evaluation of competencies for new and multidiscipline subject domains deal with scientific research and knowledge processing that evaluated by scientometric measures.

Acknowledgement. We use in this work scientific results received at the International Research and Training Centre of Information Technologies and Systems (IRTC):

1) FG 170.19 "Research and development of intellectual information technology of data processing and management in the geoallocated dynamic systems”, in particular, topic № 3 "Open semantic information technology of designing the intellectual information systems"

2) FG 170.23 "Development of an intellectual information technology of perception, recognition and content interpretations of objects of the environment, basis on the models of creative thinking".

\section{REFERENCES}

[1] Cabinet of Ministers of Ukraine. (Nov. 23, 2011). The Resolution of the Cabinet of Ministers no. 1341 "On Approval of the National Qualifications Framework". [Online]. Available: http://zakon1.rada.gov.ua/laws/show/1341-2011-\%D0\%BF. Accessed on: March 15, 2018.

[2] K. Legge, Human Resource Management: Rhetorics and Realities. London, UK: Red Globe Press, 2005.

[3] C. Bizer, R. Heese, M. Mochol, R. Oldakowski, R. Tolksdorf, and R. Eckstein, "The Impact of Semantic Web Technologies on Job Recruitment Processes"; in Proc. 7th International Conference Wirtschaftsinformatik, Bamberg, 2005, pp. 1367-1381.

doi: 10.1007/3-7908-1624-8_72.

[4] E. Biesalski, and A. Abecker, "Human Resource Management with Ontologies". In Biennial Conference on Professional Knowledge Management, Berlin, 2005, pp. 499-507. doi: 10.1007/11590019_57.

[5] F. Trichet, M. Bourse, $\bar{M}$. Leclere, and E. Morin, "Human resource management and semantic web technologies", in Proc. Information and Communication Technologies: From Theory to Applications, 2004, pp. 641-642.

doi:10.1109/ICTTA.2004.1307928. 
[6] P. Sparrow, C. Brewster, and C. Chung, Globalizing human resource management. London, UK: Routledge, 2016.

[7] L. Razmerita, A. Angehrn, and A. Maedche, "Ontology-based user modeling for knowledge management systems”. in Proc. International Conference on User Modeling, Berlin, 2003, pp. 213-217. doi:10.1007/3-540-44963-9_29.

[8] A. Gómez-Pérez, J. Ramírez, and B.Villazón-Terrazas, "An ontology for modelling human resources management based on standards", in Proc. International Conference on Knowledge-Based and Intelligent Information and Engineering Systems, 2007, Berlin, pp. 534-541.

doi: 10.1007/978-3-540-74819-9_66.

[9] Yu. Rogushina, and A. Gladun, "Ontology-based competency analysis in new research domains", Journal of Computing and Information Technology, vol. 23, no. 4, pp. 123-134, 2012.

doi: $10.2498 /$ cit.1002034.

[10] Y.V. Granovsky, "Is it possible to measure science? V.V.Nalimov's research in scientometrics", Scientometrics, vol. 52, iss. 2, pp.127-150, 2001. doi: 10.1023/A:1017991017982.

[11] P. Vinkler, "Relations of relative scientometric impact indicators. The relative publication strategy index", Scientometrics, vol. 40, iss. 1, pp. 163-169, 1997. doi: 10.1007/BF02459266.

[12] J. E. Hirsch, "An index to quantify an individual's scientific research output", in Proc. of the National academy of Sciences of the United States of America, San Diego, 2005, vol. 85, iss. 3, pp. 741-754. doi:10.1073/pnas.0507655102.

[13] L. Egghe, "The Hirsch index and related impact measures", Annual review of information science and technology, vol. 44, iss. 1, pp. 65-114, 2010. doi:10.1002/aris.2010.1440440109.

[14] L. Bornmann, and H.-D. Daniel, "The state of h index research", EMBO reports, vol. 10, iss.1, pp. 2-6, 2009. doi: 10.1038/embor.2008.233.

[15] M. Bordons, M. Fernández, I. Gómez, "Advantages and limitations in the use of impact factor measures for the assessment of research performance", Scientometrics, vol. 53, iss. 2, pp. 195-206, 2002. doi: 10.1023/A:1014800407876.

[16] T. R. Gruber, "Collective Knowledge Systems: Where the Social Web meets the Semantic Web", Web Semantics: Science, Services and Agents on the World Wide Web, vol. 6, iss. 1, pp. 4-13, 2008. doi:10.1016/j.websem.2007.11.011.

[17] A. Gladun, and Yu. Rogushina, "Use of Semantic Web Technologies and Multilinguistic Thesauri for Knowledge-Based Access to Biomedical Resources", I.J. Intelligent Systems and Applications, no. 1, pp. 11-20, 2012. doi: 10.5815/ijisa.2012.01.02.

[18] A. Gladun, and Yu. Rogushina, "Formalization of Search Context on Base of Ontologies and Multilinguistic Thesauruses", International Journal of Computing, vol. 6, iss. 3, pp. 16-22, 2007.

[19] A. Gladun, and Yu. Rogushina, Semantic Technologies: Principles and Practices. Kyiv, Ukraine: "ADEF Ukraine" Publishing House, 2016.

[20] A. Gladun, Yu. Rogushina, A. Andrushevich, and A.Kurbatski, "User-oriented Recognition of Intelligent Information Objects in Distributed Dynamic Informational Web-space", in Proc. of the 12th International Conference on Pattern Recognition and Information Processing, Minsk, 2014, pp. 1-8. 
[21] Yu. Rogushina, A. Gladun, V. Osadchiy, and S. Pryima, "Ontological analysis into the Web". Melitopol, Ukraine: MDPU im. Bogdana Hmelnickogo, 2015.

The article was received March 23, 2018.

\section{СПИСОК ВИКОРИСТАНОЇ ЛІТЕРАТУРИ}

[1] Кабінет міністрів України. (Лист. 23, 2011). Постанова Кабінету міністрів України № 1341 “Про затвердження Національної рамки кваліфікацій". [Електронний ресурс]. Доступно: http://zakon1.rada.gov.ua/laws/show/1341-2011-\%D0\%BF. Дата звернення: Бер. $15,2018$.

[2] K. Legge, Human Resource Management: Rhetorics and Realities. London, UK: Red Globe Press, 2005.

[3] C. Bizer, R. Heese, M. Mochol, R. Oldakowski, R. Tolksdorf, and R. Eckstein, "The Impact of Semantic Web Technologies on Job Recruitment Processes"; in Proc. 7th International Conference Wirtschaftsinformatik, Bamberg, 2005, pp. 1367-1381. doi: 10.1007/3-7908-1624-8_72.

[4] E. Biesalski, and A. Abecker, "Human Resource Management with Ontologies". In Biennial Conference on Professional Knowledge Management, Berlin, 2005, pp. 499-507. doi: 10.1007/11590019_57.

[5] F. Trichet, M. Bourse, $\bar{M}$. Leclere, and E. Morin, "Human resource management and semantic web technologies", in Proc. Information and Communication Technologies: From Theory to Applications, 2004, pp. 641-642. doi:10.1109/ICTTA.2004.1307928.

[6] P. Sparrow, C. Brewster, and C. Chung, Globalizing human resource management. London, UK: Routledge, 2016.

[7] L. Razmerita, A. Angehrn, and A. Maedche, "Ontology-based user modeling for knowledge management systems". in Proc. International Conference on User Modeling, Berlin, 2003, pp. 213-217. doi:10.1007/3-540-44963-9_29.

[8] A. Gómez-Pérez, J. Ramírez, and B.Villazón-Terrazas, "An ontology for modelling human resources management based on standards", in Proc. International Conference on Knowledge-Based and Intelligent Information and Engineering Systems, 2007, Berlin, pp. 534-541.

doi: 10.1007/978-3-540-74819-9_66.

[9] Yu. Rogushina, and A. Gladun, "Ontology-based competency analysis in new research domains", Journal of Computing and Information Technology, vol. 23, no. 4, pp. 123-134, 2012.

doi: $10.2498 /$ cit.1002034.

[10] Y. V. Granovsky, "Is it possible to measure science? V.V.Nalimov's research in scientometrics", Scientometrics, vol. 52, iss. 2, pp.127-150, 2001. doi: 10.1023/A:1017991017982.

[11] P. Vinkler, "Relations of relative scientometric impact indicators. The relative publication strategy index", Scientometrics, vol. 40, iss. 1, pp. 163-169, 1997. doi: 10.1007/BF02459266.

[12] J. E. Hirsch, "An index to quantify an individual's scientific research output", in Proc. of the National academy of Sciences of the United States of America, San Diego, 2005, vol. 85, iss. 3, pp. 741-754. doi:10.1073/pnas.0507655102.

[13] L. Egghe, "The Hirsch index and related impact measures", Annual review of information science and technology, vol. 44, iss. 1, pp. 65-114, 2010.

doi:10.1002/aris.2010.1440440109. 
[14] L. Bornmann, and H.-D. Daniel, "The state of h index research", EMBO reports, vol. 10, iss.1, pp. 2-6, 2009.

doi: 10.1038/embor.2008.233.

[15] M. Bordons, M. Fernández, I. Gómez, "Advantages and limitations in the use of impact factor measures for the assessment of research performance", Scientometrics, vol. 53, iss. 2, pp. 195-206, 2002. doi: 10.1023/A:1014800407876.

[16] T. R. Gruber, "Collective Knowledge Systems: Where the Social Web meets the Semantic Web", Web Semantics: Science, Services and Agents on the World Wide Web, vol. 6, iss. 1, pp.4-13, 2008.

doi:10.1016/j.websem.2007.11.011.

[17] A. Gladun, and Yu. Rogushina, "Use of Semantic Web Technologies and Multilinguistic Thesauri for Knowledge-Based Access to Biomedical Resources", I.J. Intelligent Systems and Applications, no. 1, pp. 11-20, 2012. doi: 10.5815/ijisa.2012.01.02.

[18] A. Gladun, and Yu. Rogushina, "Formalization of Search Context on Base of Ontologies and Multilinguistic Thesauruses", International Journal of Computing, vol. 6, iss. 3, pp. 16-22, 2007.

[19] А. Гладун, та Ю. Рогушина, Семантичні технологї: принщипи та практики. Київ, Україна: ТОВ «ВД «АДЕФ- Україна», 2016.

[20] A. Gladun, Yu. Rogushina, A. Andrushevich, and A.Kurbatski, "User-oriented Recognition of Intelligent Information Objects in Distributed Dynamic Informational Web-space", in Proc. of the 12th International Conference on Pattern Recognition and Information Processing, Minsk, 2014, pp. 1-8.

[21] А. Гладун, Ю. Рогушина, В. Осадчий, та С. Прийма, Онтологічний аналіз у Web". Мелітополь, Україна: МДПУ ім. Богдана Хмельницького, 2015.

\section{АНАТОЛІЙ ГЛАДУН, ЮЛІЯ РОГУШИНА, ІГОР СУБАЧ}

\section{ОНТОЛОГТЧНЕ МОДЕЛЮВАННЯ МЕНЕДЖМЕНТУ ЛЮДСЬКИМИ РЕСУРСАМИ ДЛЯ ІННОВАЦІЙНИХ ДОМЕНІВ}

У роботі запропоновані об'єктивні методи семантичного порівняння описів бізнесзадач із документами, які описують компетенції претендентів. Представлені переваги кваліфікації, що описуються через тріаду професійних якостей - знань, навичок та компетенцій. Наукова новизна цієї роботи полягає у використанні атомарних компетенцій, як основної складової оригінальної онтологічної кваліфікаційної моделі, яка виступає інструментом вирішення складної наукової проблеми кваліфікаційного підбору. Автори розробили оригінальну онтологію, яка описує відношення високого рівня роботодавців та працівників. Ця онтологія може бути інтегрована 3 онтологіями предметних областей та організаційними онтологіями, що спеціалізуються на цих відношеннях для конкретної поставленої задачі. Такий підхід може бути корисним для інноваційних областей (нових або багатопрофільних), де групи експертів та формальні специфікації професійних навичок претендентів перебувають на стадії формування. Інформація, отримана 3 природомовних документів, яка характеризує заявників, представлена онтологічними тезаурусами, які об'єктивно відображають область експертизи учасників та тезаурус проекту, побудованого за їі природомовними характеристиками. Після того визначають, наскільки співпадають ці тезауруси на семантичному рівні для того, щоб визначити, яка частина таких компетенцій відповідає потребам проекту. Ці методи забезпечують виявлення найбільш відповідних фахівців, здатних виконувати конкретні завдання у нових перспективних доменах. Пошук може бути виконаний у відкритому Web-середовищі або в природомовних документах, 
поданих заявниками. Результати цього дослідження можуть бути використані для управління людськими ресурсами при автоматизованому семантичному оцінюванні компетенцій у нових і міждисциплінарних предметних областях, пов'язаних з науковими дослідженнями та обробкою знань, які оцінюються за допомогою наукометричних показників. Запропоновані методи використовують інформацію про домен та інформацію про структуру дослідницької діяльності, формалізовану онтологіями. Ці методи засновані на семантичному узгодженні опису документів (дипломів, сертифікатів, статей, монографій, матеріалів конференцій, веб-сайтів тощо), що описують компетенцію стандартних розробників у вибраній області.

Ключові слова: компетенція, онтологія, оброблення знань, інноваційний домен, пошук людських ресурсів, управління людськими ресурсами, наукова діяльність, наукометричні показники.

АНАТОЛИЙ ГЛАДУН,

ЮЛИЯ РОГУШИНА, ИГОРЬ СУБАЧ

\section{ОНТОЛОГИЧЕСКОЕ МОДЕЛИРОВАНИЕ МЕНЕДЖМЕНТА ЧЕЛОВЕЧЕСКИМИ РЕСУРСАМИ ДЛЯ ИННОВАЦИОННЫХ ДОМЕНОВ}

В работе предложены объективные методы семантического сравнения описаний бизнес-задач с документами, которые описывают компетенции претендентов. Представлены преимущества квалификации, которые описываются через триаду профессиональных качеств - знаний, навыков и компетенций. Научная новизна этой работы состоит в использовании атомарных компетенций как основной составляющей оригинальной онтологической квалификационной модели, которая выступает инструментом решения сложной научной проблемы квалификационного подбора. Авторы разработали оригинальную онтологию, которая описывает отношения высокого уровня работодателей и работников. Эта онтология может быть интегрирована с онтологиями предметных областей и организационными онтологиями, которые специализируются на этих отношениях для конкретной поставленной задачи. Такой подход может быть полезным для инновационных областей (новых или многопрофильных), где группы экспертов и формальные спецификации профессиональных навыков претендентов находятся на стадии формирования. Информация, полученная c естественноязыковых документов, которая характеризует заявителей, представлена онтологическими тезаурусами, которые объективно отображают область экспертизы участников и тезаурус проекта, построенного за его естественноязыковыми характеристиками. Затем определяют, насколько совпадают эти тезаурусы на семантическом уровне для того, чтобы определить, какая часть таких компетенций отвечает потребностям проекта. Эти методы обеспечивают выявление наиболее соответствующих специалистов, способных выполнять конкретные задачи в новых перспективных доменах. Поиск может быть выполнен в открытой Web-среде или в естественноязыковых документах, представленных заявителями. Результаты этого исследования могут быть использованы для управления человеческими ресурсами при автоматизированном семантическом оценивании компетенций в новых и междисциплинарных предметных областях, связанных с научными исследованиями и обработкой знаний, которые оцениваются с помощью наукометрических показателей. Предложенные методы используют информацию о домене и информации о структуре исследовательской деятельности, формализованную онтологиями. Эти методы основаны на семантическом согласовании описания документов (дипломов, сертификатов, статей, монографий, материалов конференций, веб-сайтов и т.п.), которые описывают компетенцию стандартных разработчиков в выбранной области.

Ключевые слова: компетенция, онтология, обработка знаний, инновационный домен, поиск человеческих ресурсов, управление людскими ресурсами, научная деятельность, наукометрические показатели. 
Anatolii Hladun, candidate of technical sciences, associate professor, senior researcher, head of the department, International research and training center of information technologies and systems of National Academy of Sciences of Ukraine and Ministry of Education and Science of Ukraine, Kyiv, Ukraine.

ORCID: 0000-0002-4133-8169.

E-mail: glanat@yahoo.com.

Yuliia Rohushyna, candidate of physical and mathematical sciences, associate professor, senior researcher, Institute of software systems of National Academy of Sciences of Ukraine, Kyiv, Ukraine.

ORCID: 0000-0001-7958-2557.

E-mail: ladamandrak2010@gmail.com.

Ihor Subach, doctor of technical science, associate professor, head at the cybersecurity and application of information systems academic department, Institute of special communication and information protection of National technical university of Ukraine "Igor Sikorsky Kyiv polytechnic institute", Kyiv, Ukraine.

ORCID: 0000-0002-9344-713X.

E-mail: igor_subach@ukr.net.

Анатолій Ясонович Гладун, кандидат технічних наук, доцент, старший науковий співробітник, завідувач відділу Міжнародного науково-навчального центру інформаційних технологій та систем Національної Академії наук України та Міністерства науки і освіти України, Київ, Україна.

Юлія Віталіївна Рогушина, кандидат фізико-математичних наук, доцент, старший науковий співробітник Інституту програмних систем Національної Академії наук України, Київ, Україна.

Ігор Юрійович Субач, доктор технічних наук, доцент, завідувач кафедри кібербезпеки та застосування автоматизованих інформаційних систем і технологій, Інститут спеціального зв'язку та захисту інформації Національного технічного університету України "Київський політехнічний інститут імені Ігоря Сікорського", Київ, Україна.

Анатолий Ясонович Гладун, кандидат технических наук, доцент, старший научный сотрудник, заведующий отделом Международного научно-учебного центра информационных технологий и систем Национальной Академии наук Украины и Министерства науки и образования Украины, Киев, Украина.

Юлия Виталиевна Рогушина, кандидат физико-математических наук, доцент, старший научный сотрудник Института программных систем Национальной Академии наук Украины, Киев, Украина.

Игорь Юрьевич Субач, доктор технических наук, доцент, заведующий кафедрой кибербезопасности и применения автоматизированных информационных систем и технологий, Институт специальной связи и защиты информации Национального технического университета Украины "Киевский политехнический институт имени Игоря Сикорского", Киев, Украина. 